\title{
Customer Satisfaction towards Modern Banking Services of Banks with Special Reference to Vellore
}

\author{
V. S. Sivaprakash, S. Venkatesh
}

\begin{abstract}
In the present day competitive banking atmosphere, banks recurrently assess their services and products for providing superior services and innovative products to their customers. At the same time, the demand for modern services is continuously mounting among all the segments of customers. The banks are using new and modern means for not only to absorb but also to hold the customers and attain competitive advantage over their rivals through making customers satisfied and loyal. The findings explicate that customers of banks are satisfied with internet banking, on-line banking, electronic transfer, core banking, inter bank transfer and utility payment services. There is significant difference between satisfaction towards banking services of banks and profile of customers. The satisfaction towards banking services of banks is positively, significantly and moderately inter related with loyalty of customers.
\end{abstract}

Key Words: Customer, Bank, Satisfaction, Service

\section{INTRODUCTION}

The Indian banking sector has undergone tremendous transformation due to financial sector reform and this leads to opening up of banks and also new challenges for banking operations across the types of banks (Nawaz, 2017). In such crucial times of increasing and sharp competition, it is very urgent and imperative that banks have to maintain their customer base (Abdul, 2015). To accomplish this and to increase their performance, banks have to create their strategies, policies and programmes towards enhancing satisfaction of customers noticeably (Mahalakshmi and Sarvanaraj, 2011). Banks adopt modern technologies in the current days banking operations for increasing efficiency in operations and improve satisfaction of customers (Ganapathi, 2016) and also providing customized and modern services and products to customers.

In the present day competitive banking atmosphere, banks recurrently assess their services and products for providing superior services and innovative products to their customers. At the same time, the demand for modern services is continuously mounting among all the segments of customers (Agarwal, 2012). Extreme competition among different types of banks has modified the structure of the Indian banking sector.

Revised Manuscript Received on February 15, 2020.

* Correspondence Author

V. S. Sivaprakash*, Ph. D, Department of Management, PRIST Deemed to be University, Vallam, Thanjavur, Tamil Nadu, India. Email: vssivapprakash@yahoo.com

Dr. S. venkatesh, Associate Professor and Research Advisor, PRIST Deemed to be University, Vallam, Thanjavur, Tamil Nadu, India. Email: venkataatesh2011@gmail.com

(C) The Authors. Published by Blue Eyes Intelligence Engineering and Sciences Publication (BEIESP). This is an open access article under the CC BY-NC-ND license (http://creativecommons.org/licenses/by-nc-nd/4.0/)
The banks are using new and modern means for not only to absorb but also to hold the customers and attain competitive advantage over their rivals through making customers satisfied and loyal. Thus, it is important to study satisfaction of customers towards modern banking services of banks in Vellore district.

\section{METHODOLOGY}

The present investigation is done in Vellore district and 150 customers of banks are selected through random sampling method. Percentages are calculated to know profile of customers. Mean and standard deviation are computed for satisfaction of customers towards modern banking services of banks. T-test and ANOVA test are used to find difference between customers Profile and satisfaction towards modern banking services of banks. The correlation analysis is used to study inter relation between satisfaction towards modern banking services of banks and loyalty of customers.

\section{ANALYSIS AND INTERPRETATION}

\subsection{Customers profile}

The Customers profile of Banks is disclosed in Table1 Table-1.Customers Profile

\begin{tabular}{|l|c|c|}
\hline \multicolumn{1}{|c|}{ Profile } & \multicolumn{1}{c|}{$\begin{array}{c}\text { Number of } \\
\text { Customers }\end{array}$} & Percentage \\
\hline \multicolumn{1}{|c|}{ Sex } & & \\
\hline Male & 82 & 54.67 \\
\hline Female & 68 & 45.33 \\
\hline \multicolumn{1}{|c|}{ Age } & 53 & 35.33 \\
\hline $21-30$ years & 64 & 42.67 \\
\hline $31-40$ years & 33 & 22.00 \\
\hline $41-50$ years & 27 & 18.00 \\
\hline \multicolumn{1}{|c|}{ Qualification } & 35 & 23.33 \\
\hline Secondary & 31 & 20.67 \\
\hline Higher Secondary & 57 & 38.00 \\
\hline Diploma & & \\
\hline Graduation & 28 & 18.67 \\
\hline Monthly Salary (Rs.) & 60 & 40.00 \\
\hline Less than Rs.25,000 & 36 & 24.00 \\
\hline Rs.25,001 - Rs.30,000 & 26 & 17.33 \\
\hline Rs.30,001 - Rs.35,000 & & \\
\hline More than Rs.35,000 & & \\
\hline 54.67 per cent 0 c & & \\
\hline
\end{tabular}

54.67 per cent of customers of banks are males, and 45.33 per cent of them are females.42.67 per cent of customers are in the age group of $31-40$ years, 22.00 per cent belongs

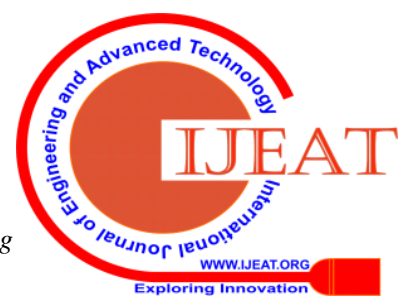


to the age group of $41-50$ years.

The findings explain that 38.00 per cent of them are graduates, 18.00 per cent of them are secondary education and 40.00 per cent of them are having monthly income of Rs.25,001 - Rs.30,000, 17.33 per cent of them are having monthly income of more than Rs.35,000.

\subsection{Satisfaction of Customers towards Modern Banking}

\section{Services of Banks}

The satisfaction of customers towards modern banking services of banks is given in Table-2.

Table-2. Customers satisfaction towards Moder Banking Services of banks

\begin{tabular}{|l|c|c|}
\hline \multicolumn{1}{|c|}{ Modern Banking Services } & Mean & $\begin{array}{c}\text { Standard } \\
\text { Deviation }\end{array}$ \\
\hline Home Banking & 3.37 & 0.91 \\
\hline Internet Banking & 3.76 & 0.88 \\
\hline Tele-Banking & 3.35 & 0.99 \\
\hline On-line Banking & 3.92 & 0.86 \\
\hline Mobile Banking & 3.38 & 0.95 \\
\hline Electronic Transfer & 3.70 & 0.79 \\
\hline Core Banking & 3.96 & 0.80 \\
\hline SMS Banking & 3.39 & 0.93 \\
\hline Inter Bank Transfer & 3.74 & 0.84 \\
\hline Utility Payment Services & 3.88 & 0.87 \\
\hline
\end{tabular}

The customers of banks are satisfied with internet banking, on-line banking, electronic transfer, core banking, inter bank transfer and utility payment services, while, they and SMS banking.

\section{CUSTOMERS PROFLIE AND SATISFACTION TOWARDS MODERN BANKING SERVICES OF BANKS}

To identify difference between customers profile and satisfaction towards modern banking services of banks, T-test and ANOVA test are carried out and the results are shown inTable-3.

Table-3. Customers Profile and Satisfaction towards Modern Banking Services of banks

\begin{tabular}{|l|c|c|}
\hline \multicolumn{1}{|c|}{ Particulars } & $\begin{array}{c}\text { t-Value / } \\
\text { F-Value }\end{array}$ & Sig. \\
\hline $\begin{array}{l}\text { Gender and Satisfaction towards } \\
\text { Modern Banking Services of banks }\end{array}$ & $\begin{array}{c}5.974^{* *} \\
\text { (t-value) }\end{array}$ & .000 \\
\hline $\begin{array}{l}\text { Age Group and Satisfaction towards } \\
\text { Modern Banking Services of banks }\end{array}$ & $8.460^{* *}$ & .000 \\
\hline $\begin{array}{l}\text { Education and Satisfaction towards } \\
\text { Modern Banking Services of banks }\end{array}$ & $9.215^{* *}$ & .000 \\
\hline $\begin{array}{l}\text { Monthly Income and Satisfaction } \\
\text { towards Modern Banking Services of } \\
\text { banks }\end{array}$ & $8.738^{* *}$ & \\
\hline
\end{tabular}

** Significant at $1 \%$ level

The F-values and T-value and are significant one per cent level elucidating significant difference exits in satisfaction are neutral with home banking, tele-banking, mobile banking

towards modern banking services of banks among profile of customers. Therefore,rejects null hypothesis.

\section{V.INTER RELATION BETWEEN SATISFACTION TOWARDS MODERN BANKING SERVICES OF banks AND LOYALTY OF CUSTOMERS}

The inter relation between satisfaction towards modern banking services of banks and loyalty of customers was deliberate by correlation analysis and the result is shown in Table-4

\section{Table-4. Inter Relation between Satisfaction towards Modern Banking Services of banks and Loyalty of Customers}

\begin{tabular}{|l|c|}
\hline \multicolumn{1}{|c|}{ Particulars } & Correlation Co-efficient \\
\hline Satisfaction towards Modern Banking & $0.57^{* *}$ \\
Services of banks and Loyalty Of \\
Customers
\end{tabular}

\section{** Significant at $1 \%$ level}

The correlation co-efficient between satisfaction towards modern banking services of banks and customers Loyalty is 0.57, it is moderately and Positively inter related with each other at 1 per cent level of significant. So, reject null hypothesis .

\section{CONCLUSION}

The results elucidate the customers of banks are satisfied with internet banking, on-line banking, electronic transfer, core banking, inter bank transfer and utility payment services. The findings show evidence of that there is significant difference between satisfactions towards modern banking services of banks and profile of customers. The satisfaction towards modern banking services of banks is positively, significantly and moderately inter related with loyalty of customers. Therefore, banks should improve services of home banking, tele-banking, mobile banking and SMS banking to enhance loyalty of customers and drag more customers in the coming years towards them.

\section{REFERENCES:}

1. Aayasha Nawaz, (2017), “Customer's Satisfaction towards Banking Services of State Bank of India in Uttar Pradesh", International Journa of Commerce and Management Research, 3(12), pp. 8-12.

2. Abdul, R.A., (2015), "Customer's Satisfaction towards Banking Services of State Bank of India in Kanyakumari District", International Journal of management and commerce innovations, 2(2), pp.429-442.

3. Doddaraju, M.E., (2013), "Customer Satisfaction towards Public and Private Sector Banking Services with Special Reference to Anantapur District of Andra Prades]", Global Journal of Management and Business Studies, 3(3), pp. 287-294.

4. Ganapathi, R., (2016), "Customer Satisfaction of Private Sector Banks in Madurai city, Tamil Nadu", Journal of Management Research and Analysis, 3(2),pp. 67-73.

5. Roger Hallowell, (1996), "The Relationship of Customer Satisfaction, Customer Loyalty and Profitability: An Empirical Study" The International of Service Industry Management, 7(4), pp.27-42.

6. Jyoti Agarwal, (2012), "Customer Satisfaction in Indian Banking Services-A Study in Aligarh District", International Journal of Computing and Business Research, 3(1), pp.1-14.

7. Mahalakshmi, V. and Sarvanaraj, M., (2011), "A Study on Customers' Satisfaction towards Banking Services in Trichy", Interdisciplinary Journal of Contemporary Research in Business, 3(4), pp.237-253. 
8. Naveen, K. and Gangal, V.K., (2011), "Customer Satisfaction in banks-A Case Study of HDFC Bank", International Referred Research Journal, 11(4), pp.177-186.

9. Pratap Chandra Mandal, (2015), "Customer Satisfaction in Indian Retail Banking-A Qualitative Perspective", International Journal of Applied Research, 1(2), pp. 54-63.

10. Singh, S. and Arora, R., (2011), "A Comparative Study of Banking Services and Customer Satisfaction in Public, Private and Foreign Banks", Journal of Economics, 2(1), pp. 45-56.

11. Vigg Silky, Mathur Garima and Holani Umesh, (2007), "Customer Satisfaction in Banking Services: A Comparative Study of Public and Private Sector Banks". The Journal of Indian Management and Strategy, 12(2), pp 24-30.

\section{AUTHORS PROFILE}

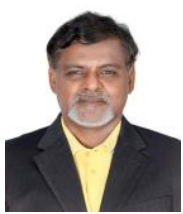

Mr. V. S. Sivaprakash, is having banking experience of 23 years and he is working as a professional assurance consultant in banking.He is having interest in guiding young bloods in banks and intrrnal auditiors. He started his career with SBI then joined in AXIS bank as Internal auditor.He played various roles as officer,Branch Manager,Operational Manager,Divisional Head, Orgainsational Development facilitator and head of investigation on bank fraud

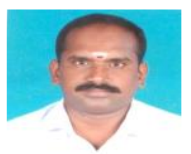

Dr. S. Venkatesh is working as Associate Professor and Research advisor at PRIST School of Business, PRIST University, Thanjavur.His qualification is MBA.M.Phil.,MA(LM).,Ph.D.He has qualified State Eligibility Test in the year 2016.He is having 16 years of Experience in Academic.He is a Life Member of Indian Society of Technical Education..At present he is guiding 8 Ph.D Students and he has Published 20 papers in Reputed international Journals. 